Sains Malaysiana 49(8)(2020): 1915-1924

http://dx.doi.org/10.17576/jsm-2020-4908-13

\title{
A Green Nutraceutical Study of Antioxidants Extraction in Cleome brachycarpa - An Ethnomedicinal Plant
}

(Suatu Kajian Nutraseutik Hijau Pengekstrakan Antioksidan dalam Cleome brachycarpa - Suatu Tumbuhan Etnoubatan)

Tahira Saleem, Ayesha Sumra, SAmra Khan*, Maryam Zain, Warda Hassan, Sehrish Mehdi, Noor-UlAIN WAHID, SAMRAH KANWAL \& TEHSEEN GULL

\begin{abstract}
In the present study, an indigenous medical plant 'Cleome brachycarpa' was comparatively investigated for its antioxidant extraction for first time; using the soxhlet (traditional), microwave-assisted, and ultrasound-assisted (green) extraction methods with seven different solvents. The microwave-assisted extraction with methanol as solvent recovered the phytochemicals two-folds higher than the other methods with extraction efficiency of $370.57 \pm 0.49 \mu \mathrm{g} /$ $m g$ and correspondingly extracted the polyphenols: Phenolics (74.17 $\pm 0.61 \mu \mathrm{g}$ GAE/mg DW), Flavonoids (65.46 \pm $0.40 \mu \mathrm{g} Q \mathrm{QE} / \mathrm{mg} \mathrm{DW})$, and Tannins $(55.97 \pm 0.85 \mu \mathrm{g} C E / \mathrm{mg} \mathrm{DW})$. The antioxidant capacity in relation with polyphenols was determined for Free radical scavenging activity and total antioxidant potential. The DPPH radical scavenging percentage of methanolic green extract of Cleome brachycarpa was found to be $81.37 \pm 0.28$ with IC ${ }_{50}$ of 0.30 $\mathrm{mg} / \mathrm{mL}$ that matched up to the DPPH scavenging potential of Trolox. Furthermore, the ferric reducing potential was high up to $15.30 \pm 0.30 \mu \mathrm{g}$ GAE/mg DW. The correlation of antioxidant capacity with polyphenols was highly significant $(p<0.05)$. The green nutraceutical study has validated the ethnomedicinal importance of Cleome brachycarpa which is related to its high polyphenolic content. The findings highlight Cleome brachycarpa as a potential candidate for research and isolation of medicinal polyphenols.
\end{abstract}

Keywords: Antioxidants; Cleome brachycarpa; microwave-assisted extraction; nutraceutical extraction; polyphenols; ROs scavenging

\section{ABSTRAK}

Dalam kajian ini, tumbuhan ubat yang asli 'Cleome brachycarpa' telah dikaji bagi pengekstrakan antioksidannya untuk pertama kali; menggunakan kaedah pengekstrakan soxhlet (tradisi), berbantu mikrogelombang dan berbantu ultrabunyi (hijau) dengan tujuh pelarut yang berbeza. Pengekstrakan berbantu mikrogelombang dengan metanol sebagai pelarut memperoleh fitokimia dua kali ganda lebih tinggi daripada kaedah lain dengan kecekapan pengekstrakan $370.57 \pm 0.49 \mu \mathrm{g} / \mathrm{mg}$ dan juga mengekstrak polifenol berikut: Fenolik (74.17 $\pm 0.61 \mu \mathrm{g} \mathrm{GAE} / \mathrm{mg} \mathrm{DW}$ ), Flavonoid (65.46 $\pm 0.40 \mu \mathrm{g} Q \mathrm{QE} / \mathrm{mg} \mathrm{DW}$ ) dan tanin (55.97 $\pm 0.85 \mu \mathrm{g} C E / \mathrm{mg} \mathrm{DW})$. Hubungan antara kapasiti antioksidan dengan polifenol ditentukan untuk aktiviti hapus-sisa radikal bebas dan jumlah potensi antioksidan. Peratusan hapus-sisa radikal bebas DPPH bagi ekstrak hijau metalonik Cleome brachycarpa ialah $81.37 \pm 0.28$ dengan IC sebanyak $0.30 \mathrm{mg} / \mathrm{mL}$ yang sepadan dengan potensi hapus-sisa DPPH Trolox. Tambahan pula, potensi pengurangan ferik mencapai setinggi $15.30 \pm 0.30 \mu \mathrm{g}$ GE/mg DW. Hubungan kapasiti antioksidan dengan polifenol adalah sangat ketara $(p<0.05)$. Kajian nutraseutik hijau telah mengesahkan kepentingan etnoubatan Cleome brachycarpa yang berkait dengan kandungan polifenoliknya yang tinggi. Hasil kajian menunjukkan Cleome brachycarpa sebagai calon yang berpotensi untuk penyelidikan dan pengasingan ubat polifenol.

Kata kunci: Antioksidan; Cleome brachycarpa; hapus-sisa ROs; pengekstrakan berbantu mikrogelombang; pengekstrakan nutraseutik; polifenol

\section{INTRODUCTION}

The buildup of free radicals in cells disturbs the redox balance and result in oxidative stress which is attributed for inflammation, rheumatism, dermatosis, and other major health problems like cardiovascular diseases and cancer (Bhattacharyya et al. 2014). The antioxidant capacity of herbal medicines is a known fact and it is one of the reasons for the reliance of four billion people (up to $80 \%$ of the total world's populace) on plant-derived medicine (Ekor 2013) - emphasizing the importance of medicinal flora in heath care of mankind.

The medicinal properties of plants are attributed to the diverse classes of phytochemicals, also known as secondary metabolites. Polyphenols is one of the largest and substantial phytochemical classes, widely recognized for its medicinal and chemo-preventative properties. The class 
of polyphenols is categorized into the main sub-classes of phenolics, flavonoids, and tannins (Flores-Córdova et al. 2017)B. The number and position of hydroxyl groups in polyphenols ascribes the extend of antioxidant (Tsao 2010).

Among medicinal plants, Genus Cleome of Capparidaceae family (Ali \& Qaiser 2001), comprising of estimated 200 species is well acknowledged for its ethnomedicinal and ethnobotanical uses. Several studies have endorsed antimicrobial, antinociceptive, cytotoxic, hepatoprotective, and anti-inflammatory potentials of Cleome species (Gupta \& Vinod 2009; Moridi Farimani et al. 2017; Mothana \& Ulrike 2005). From this genus, Cleome brachycarpa (Figure 1) is an ethnomedicinal plant, indigenously used for gastrointestinal disorders, joints pain and inflammation in various regions of Pakistan (Abdul Ghani et al. 2012; Hameed et al. 2011; Mussarat et al. 2014).

The quantitative and qualitative analysis of bioactive compounds from plants mainly depends on the choice of the suitable extraction technique (Sasidharan et al. 2011). That is why extraction techniques has greater influenced on the scope of pharmacognostical studies of medicinal plants and since the inception, approach of green chemistry, pharmacognosy has progressed exponentially (Azmir et al. 2013; Smith 2003). There are several extraction procedures for the extraction of plant materials. First, conventional extraction methods in which Soxhlet is still believed as one of the referenced method to compare occurrence of freshly formulated techniques (Azmir et al. 2013). Microwave-assisted extraction has been described as an excellent green extraction technology for the study of Polyphenols (Mustapa et al. 2015).

For Cleome brachycarpa, only diminutive literature can to be found for its extraction and nutraceutical properties to lay scientific grounds to its ethnomedicinal use. Hence, impelled by the ethnomedicinal uses of Cleome brachycarpa, present study aimed to identify the most suitable extraction method for extraction of polyphenols of Cleome brachycarpa via soxhlet, microwave-assisted and ultrasonic-assisted extraction methods. Finding microwave-assisted extraction to most efficient and green among the other methods, we further compared the recovery of polyphenols in different solvents in the microwave-assisted extraction and studied the antioxidant potential of the extracts to elaborate on the nutraceutical potential of Cleome brachycarpa for its excellent antioxidant properties.

\section{MethodS AND MATERIALS}

\section{STUDY DESIGN}

To evaluate the antioxidant capacity of Cleome brachycarpa in relation with green extraction of Polyphenols, primarily the extraction methods were

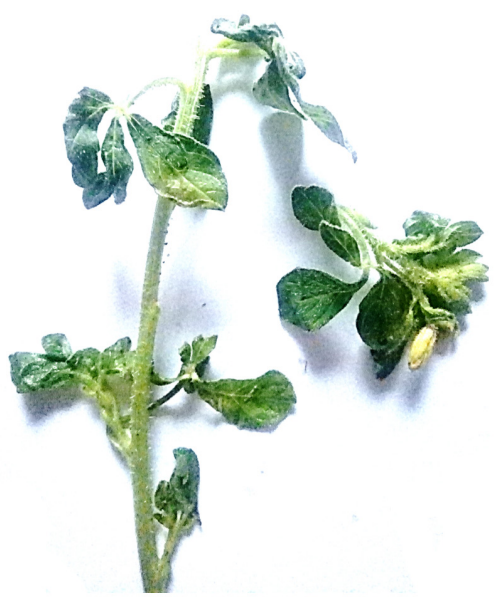

FIGURE 1. Cleome brachycarpa

compared. The green extraction using microwave (MAE) and ultrasound (UAE) technologies and the traditional extraction method of soxhlet extraction (SE). The most yielding method's extracts were studied for the Polyphenols estimation along the antioxidant capacity.

\section{CHEMICALS AND INSTRUMENTATION}

Analytical grade chemicals and solvents, bought from Sigma Aldrich, were used. The instruments for extraction included Dawlance's DW+80 Microwave, Auto-Science Elmaronic's Ultrasonic Cleaner E-60-H and SciLabware's
Soxhlet EX0104. The extracts were concentrated using Heidolph's Hei-VAP Rotary Evaporator and in antioxidant assessments, SHEL LAB's SMI6 Digital Laboratory Incubator was used. Dynamica's HALO DB-20 UV-VIS Double Beam Spectrophotometer was used for spectroscopic determination.

\section{PLANT COLLECTION AND PRETREATMENT}

The sample of Cleome brachycarpa were collected from Dera Ghazi Khan, Punjab, Pakistan. The plant sample was firstly dry cleaned followed by shade drying. The dried 
plant sample was pulverized and was sieved against the mesh size of 100 (149 microns). Prior to extraction, plant sample was defatted using 1:10 $\mathrm{g} / \mathrm{mL}$ maceration in the petroleum ether.

\section{EXTRACT PREPARATION}

Seven solvents offering wide range of polarity were used in three extraction technologies - namely n-hexane, ethyl acetate, chloroform, dichloromethane, acetone, ethanol, and methanol.

\section{MICROWAVE ASSISTED EXTRACTION}

With required adaptions, Microwave-Assisted Extraction (Yasmeen \& Hassnain 2016) was carried out. $5 \mathrm{~g}$ of defatted plant sample of Cleome brachycarpa was added to $30 \mathrm{~mL}$ of respective solvents. In covered vials, the mixtures were treated with microwaves for $15 \mathrm{~min}$. Afterwards, the radiated samples were filtered out and the surplus solvent was removed using rotary evaporator. The resultant dry extract (referred as dry weight or DW in paper) was weighed out to measure the extraction efficiency and percentage recovery. Subsequently, the extracts were dissolved in their parent solvents to make up the concertation of $10 \%$ and were stored $4{ }^{\circ} \mathrm{C}$ for further study. The procedure was replicated thrice for accurate results.

\section{ULTRASOUND-ASSISTED EXTRACTION}

The Ultrasound-Assisted Extraction of defatted plant sample Cleome brachycarpa was effectuated with modifications (Vinatoru et al. 2017). $5 \mathrm{~g}$ of defatted plant sample was commingled with $100 \mathrm{~mL}$ of respective solvents in sealed vessels. For $3 \mathrm{~h}$, the vessels were radiated in the ultrasonic bath at the constant temperature of $\left(40^{\circ} \mathrm{C}\right)$. The post-radiation treatment of extracts was done (as described in procedure of MA extraction).

\section{SOXHLET EXTRACTION}

Soxhelt extraction was adapted with modications (Lopresto et al. 2014) by commingling defatted plant sample with $150 \mathrm{~mL}$ of respective solvents and were reflux condensed in soxhlet apparatus for $5 \mathrm{~h}$. The temperature was maintained as per the requirement of solvents. The post-treatment of extracts was done (as described in procedure of MA extraction).

\section{QUALITATIVE SCREENING OF PHYTOCHEMICALS}

The stored $10 \%$ microwave-assisted extracts of Cleome brachycarpa were screened for 17 phytochemicals with standard phytochemical screening tests (Farnsworth 1966).

\section{ESTIMATION OF POLYPHENOLS TOTAL PHENOLIC CONTENT}

The TPC in Cleome brachycarpa green extracts were determined by adjusting the spectrophotometric FolinCiocalteu assay (Zapata et al. 2017). $100 \mu \mathrm{L}$ of each extract was diluted 10 times and was then treated with $1.25 \mathrm{~mL}$ of
Folin-Ciocalteu reagent and $400 \mu \mathrm{L}$ of sodium carbonate solution $(10 \% \mathrm{w} / \mathrm{v})$. After incubation of $30 \mathrm{~min}$ at room temperature in dark, the absorbance was measured at 765 $\mathrm{nm}$. The standard curve was obtained by applying FC assay to the different concentrations of Gallic Acid (200$1000 \mu \mathrm{g} / \mathrm{mL}$ ). The TPC in Cleome brachycarpa green extracts was represented as $\mu \mathrm{g}$ of Gallic Acid Equivalent per the mg of dry weight ( $\mu$ g GAE/mg DW). The assay was replicated thrice.

\section{TOTAL FLAVONOID CONTENT}

Aluminum Chloride $\left(\mathrm{AlCl}_{3}\right)$ assay for TFC estimation was followed (Zarza-García et al. 2017) with slight adaption. $1 \mathrm{~mL}$ of each Cleome brachycarpa green extract was diluted by mixing $4 \mathrm{~mL}$ of distilled water followed by addition of $300 \mu \mathrm{L}$ of sodium nitrite solution $(5 \% \mathrm{w} / \mathrm{v})$. This mixture was left to rest for $5 \mathrm{~min}$. Afterwards, 300 $\mu \mathrm{L}$ aluminum chloride solution $(10 \% \mathrm{w} / \mathrm{v})$ and $2 \mathrm{~mL}$ of sodium hydroxide solution (1 M) was added and volume made up to $10 \mathrm{~mL}$ with distilled water and absorbance was taken at $415 \mathrm{~nm}$. The standard curve was obtained by applying $\mathrm{AlCl}_{3}$ Assay to the different concentrations of Quercetin (200-1000 $\mu \mathrm{g} / \mathrm{mL})$. Total flavonoid content was represented as $\mu \mathrm{g}$ of Quercetin per mg of dry weight ( $\mu \mathrm{g} \mathrm{QE} / \mathrm{mg} \mathrm{DW})$. The assay was replicated thrice.

\section{TOTAL TANNINS CONTENT}

Vanillin Assay (Flores-Córdova et al. 2017) was employed with modifications to estimate the condensed Tannins. The fresh reagent for the assay was prepared by mixing HCL in methanol $(8 \% \mathrm{v} / \mathrm{v})$ and vanillin solution in methanol (4\%) by equal ration. $1 \mathrm{~mL}$ of extract solution was added to $4 \mathrm{~mL}$ of Vanillin assay reagent and was heated for $20 \mathrm{~min}$ at $30{ }^{\circ} \mathrm{C}$. After the reaction took place, the prepared sample was measured at $500 \mathrm{~nm}$. The standard curve was obtained by applying Vanillin Assay to the different concentrations of Catechin (200-1000 $\mu \mathrm{g} / \mathrm{mL})$. The condensed tannin content was represented as $\mu \mathrm{g}$ equivalent of catechin per mg of dry weight ( $\mu \mathrm{g} \mathrm{CE} / \mathrm{mg}$ DW).

\section{ESTIMATION OF ANTIOXIDANT POTENTIAL $\mathrm{DPPH} \bullet \mathrm{SCAVENGING} \mathrm{ACTIVITY}$}

The ROs scavenging capacity (Ashraf et al. 2014) was estimated by taking $3.9 \mathrm{~mL}$ of different concentrations $(50-800 \mu \mathrm{g} / \mathrm{mL})$ of Cleome brachycarpa green extracts and were reacted with $0.1 \mathrm{~mL}$ of DPPH solution in methanol $(0.1 \mathrm{mM})$. The vials were incubated for $30 \mathrm{~min}$ at room temperature. Afterwards, the absorbance was measured at with spectrophotometer. Trolox was used as a positive control. The $\mathrm{IC}_{50}$ was calculated from the obtained data. The inhibition percentage of DPPH radicals was calculated as:

Inhibition $\%$ of DPPH radicals $=\mathrm{A}_{\text {blank }}-\mathrm{A}_{\text {sample }} / \mathrm{A}_{\text {blank }} \times 100$

TOTAL ANTIOXIDANT POTENTIAL

Ferric reducing antioxidant assay was used to estimate 
the total antioxidant potential (Ngo et al. 2017). To 2.5 $\mathrm{mL}$ potassium ferricyanide $(1 \% \mathrm{w} / \mathrm{v}), 1 \mathrm{~mL}$ of extract of different concentrations $(25-200 \mu \mathrm{g} / \mathrm{mL})$ was added and was incubated at $50{ }^{\circ} \mathrm{C}$ for $25 \mathrm{~min}$. Afterwards, the reaction was stopped by adding $2.5 \mathrm{~mL}$ of trichloroacetic acid solution $(10 \% \mathrm{w} / \mathrm{v})$. An aliquot of $2.5 \mathrm{~mL}$ of resultant solution was added to $2.5 \mathrm{~mL}$ of water and $500 \mu \mathrm{L}$ of $\mathrm{FeCl}_{3}$ solution $(1 \% \mathrm{w} / \mathrm{v})$. The mixture was allowed to rest for $30 \mathrm{~min}$ and then absorbance was measured at 700 $\mathrm{nm}$ and the total antioxidant potential was expressed as $\mu \mathrm{g}$ GAE per mg of dry weight. The experiment was replicated thrice.

\section{STATISTICAL ANALYSIS}

Phytochemical Screening was evaluated via SPSS (version 22) whereas for determination of significant difference $(\mathrm{p}<0.05)$, ANOVA, post-hoc tests and correlation of polyphenols to antioxidant capacity, Minitab (version 18) was used.

\section{RESULTS AND DISCUSSION}

EXTRACTION EFFICIENCY

The results have indicated that extraction efficiency from Cleome brachycarpa is significantly dependent on the extraction technologies as tabulated in Table 1. Moreover, the choice of solvent for respective extraction technology whether green or traditional had high impact on percentage recovery. Microwave-assisted extraction resulted up to $37 \%$ yield as compared to ultrasoundassisted extraction and soxhlet extraction which recovered $27 \%$ and $19.29 \%$, respectively. The findings have shown that the order of highest to lowest extraction efficiency of solvents is methanol, ethanol, ethyl acetate, acetone, $n$-hexane, and chloroform $\sim$ dichloromethane. The influence of polarity of solvent is evident as also endorsed by previous studies (Do et al. 2014). The methanolicmicrowaved-assisted extract yielded $370 \mathrm{mg} / \mathrm{g}$ whereas ultrasound-assisted extraction and soxhlet extraction only recovered 278.6 and $198.87 \mathrm{mg} / \mathrm{g}$, respectively. The results have demonstrated that the microwave-assisted extraction yields almost one-fold more than ultrasoundassisted extraction and two-folds more than soxhlet extraction. The pretreatment involved defatting prior to extraction which may also affect the yield overall.

TABLE 1. Comparative extraction of Cleome brachycarpa

\begin{tabular}{|c|c|c|c|c|c|}
\hline & Extracts & Extraction solvent & $\begin{array}{l}\text { Extract } \\
(\mathrm{mg} / \mathrm{g})\end{array}$ & $\begin{array}{c}\text { RSD } \\
\%\end{array}$ & $\%$ Extraction \\
\hline \multirow{6}{*}{ 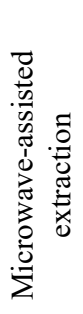 } & $\mathrm{C}_{\mathrm{B}} \mathrm{M} 1$ & n-Hexane & & 0.32 & 5.112 \\
\hline & $\mathrm{C}_{\mathrm{B}} \mathrm{M} 2$ & Ethyl Acetate & & 0.52 & 19.4 \\
\hline & $\mathrm{C}_{\mathrm{B}} \mathrm{M} 3$ & Chloroform & & 0.73 & 3.96 \\
\hline & $\mathrm{C}_{\mathrm{B}} \mathrm{M} 4$ & Dichloromethane & & 0.59 & 3.66 \\
\hline & $\mathrm{C}_{\mathrm{B}} \mathrm{M} 5$ & Acetone & & 0.56 & 17.8 \\
\hline & $\mathrm{C}_{\mathrm{B}} \mathrm{M} 6$ & Ethanol & & 0.29 & 34.2 \\
\hline \multirow{7}{*}{ 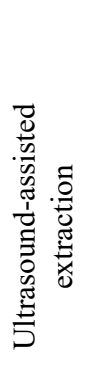 } & $\mathrm{C}_{\mathrm{B}} \mathrm{M} 7$ & Methanol & & 0.16 & 37.12 \\
\hline & $\mathrm{C}_{\mathrm{B}} \mathrm{U} 1$ & n-Hexane & & 0.68 & 3.668 \\
\hline & $\mathrm{C}_{\mathrm{B}} \mathrm{U} 2$ & Ethyl Acetate & & 0.40 & 14.4 \\
\hline & $\mathrm{C}_{\mathrm{B}} \mathrm{U} 3$ & Chloroform & & 0.93 & 3.48 \\
\hline & $\mathrm{C}_{\mathrm{B}} \mathrm{U} 4$ & Dichloromethane & & 0.47 & 3.22 \\
\hline & $\mathrm{C}_{\mathrm{B}} \mathrm{U} 5$ & Acetone & & 0.52 & 11.2 \\
\hline & $\mathrm{C}_{\mathrm{B}} \mathrm{U} 6$ & Ethanol & & 0.16 & 23.52 \\
\hline \multirow{8}{*}{ 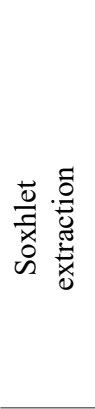 } & $\mathrm{C}_{\mathrm{B}} \mathrm{U} 7$ & Methanol & & 0.26 & 27.74 \\
\hline & $\mathrm{C}_{\mathrm{B}} \mathrm{S} 1$ & n-Hexane & & 0.97 & 3.436 \\
\hline & $\mathrm{C}_{\mathrm{B}} \mathrm{S} 2$ & Ethyl Acetate & & 0.82 & 12.2 \\
\hline & $\mathrm{C}_{\mathrm{B}} \mathrm{S} 3$ & Chloroform & & 0.61 & 3.26 \\
\hline & $\mathrm{C}_{\mathrm{B}} \mathrm{S} 4$ & Dichloromethane & & 0.66 & 3.14 \\
\hline & $\mathrm{C}_{\mathrm{B}} \mathrm{S} 5$ & Acetone & & 0.61 & 9.4 \\
\hline & $\mathrm{C}_{\mathrm{B}} \mathrm{S} 6$ & Ethanol & & 0.64 & 18.2 \\
\hline & $\mathrm{C}_{\mathrm{B}} \mathrm{S} 7$ & Methanol & & 0.41 & 19.96 \\
\hline
\end{tabular}

The extraction efficiency is presented as the average of three individual experiments. Different alphabets in subscript demonstrates significant $(\mathrm{p}<0.05)$ difference within various methods among different solvents 
The stimulating part is the 'green conditions' (Cvjetko et al. 2015) of microwave-assisted extraction. In terms of time, MAE only needed 15 min treatment and yielded highest; UAE took $180 \mathrm{~min}$ and SE required $300 \mathrm{~min}$. Solvent consumption was also 3 to 5 times less in MAE as compared to the UAE and SE, respectively. The pooled standard deviation for the means of three individual experiments calculated to be 0.0521 signifying the reproducibility and reliability of the findings. The resulted extraction efficiencies when set for ANOVA and post-hoc tests, showed significant difference $(p<0.05)$ among each sample whereas the Tukey's Simultaneous Test for differences in means resulted $96.6 \%$ of individual confidence level. The present study has shown that in increasing need of rapid, inexpensive, efficient and green extraction methods, the MAE is indeed one for Cleome brachycarpa.

PHYTOCHEMICAL SCREENING

All the microwave-assisted extracts of from Cleome brachycarpa were tested against qualitative phytochemical screening for 16 secondary metabolites. The results were compared using SPSS version 16 (Figure 2). As the microwave-assisted extraction yielded highest, it was contemplated to study those extracts onwards for in depth look in secondary metabolites of Cleome brachycarpa. The polarity of solvents and solubility of phytochemicals played the most important role in the phytochemical extraction. In terms of antioxidants, the polyphenols were largely extracted by methanol, ethanol, ethyl estate, and acetone in their polar nature. Similar phytochemicals extraction from Cleome arabica (Aicha et al. 2017) has been reported previously. The extraction of specific phytochemicals supported the percentage recovery in respective solvents. Although Phytochemical Screening does not offer the definitive results yet helps in understanding and shaping the study onwards.

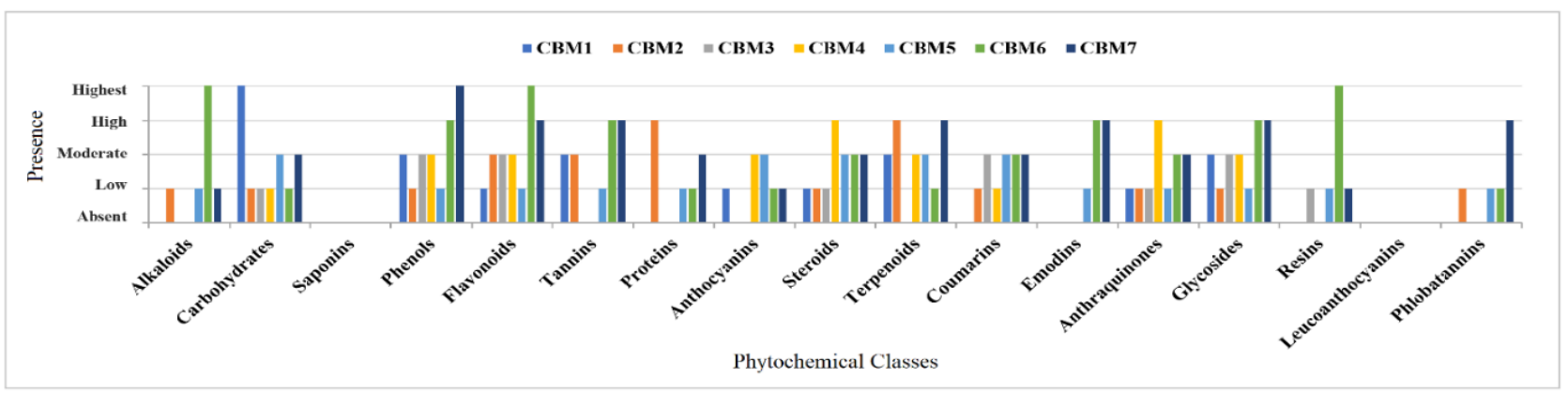

FIGURE 2. Abundance of various phytochemicals in microwave-assisted extracts of Cleome brachycarpa

\section{GREEN EXTRACTION OF POLYPHENOLS}

Polyphenols are primarily responsible for antioxidant potential of medicinal plants. Our findings showed that extractions of phenolics, flavonoids, and tannins were significantly impacted $(p<0.05)$ by the solvents. Although the findings from extraction efficiency and phytochemical screening indicated that $\mathrm{C}_{\mathrm{B}} \mathrm{M} 7$ and $\mathrm{C}_{\mathrm{B}} \mathrm{M} 6$ were the optimal samples for polyphenolic and antioxidant study yet the diverse nature of polyphenols and their nonpolar adjuvants influenced the study to include $\mathrm{C}_{\mathrm{B}} \mathrm{M} 7$, $\mathrm{C}_{\mathrm{B}} \mathrm{M} 6$ and $\mathrm{C}_{\mathrm{B}} \mathrm{M} 1$ as well for better outlook on antioxidant capacity of Cleome brachycarpa.

Supporting the discussed results, the methanolic extract from microwave-assisted extraction significantly ( $p$
$<0.05)$ surpassed rest of the extracts and resulted extraction of phenolics by $74.17 \pm 0.61 \mu \mathrm{g}$ GAE$/ \mathrm{mg}$ of dry weight tannins by $53.06 \pm 0.67 \mu \mathrm{g} \mathrm{CE} / \mathrm{mg} \mathrm{DW}$. Ethanol extracted flavonoids slightly more than methanol, giving $67.42 \pm$ $0.51 \mu \mathrm{g}$ QE/mg DW The TPC from methanolic extract of Cleome brachycarpa in present study is much higher than that has been reported for $C$. iberica (Moridi Farimani et al. 2017) and C. viscaosa (Bainiwal et al. 2013). Both extracted quantities of flavonoids and tannins are significantly higher than previously reported studies (Aicha et al. 2017). The pooled STDs were found to be $0.63,0.52$, and 0.76 for TPC, TFC, and TTC, respectively, whereas the individual confidence level were $>98.5 \%$ for all three data sets. 
TABLE 2. Polyphenolic content in green extracts of Cleome brachycarpa

\begin{tabular}{cccc}
\hline $\mathrm{C}_{\mathrm{B}} \mathrm{Es}$ & $\begin{array}{c}\text { Total phenolic } \\
\text { content } \\
(\mu \mathrm{g} \mathrm{GAE} / \mathrm{mg} \mathrm{DW})^{*}\end{array}$ & $\begin{array}{c}\text { Total flavonoid } \\
\text { content } \\
(\mu \mathrm{g} \mathrm{QE} / \mathrm{mg} \mathrm{DW})^{* *}\end{array}$ & $\begin{array}{c}\text { Total tannins content } \\
(\mu \mathrm{g} \mathrm{CE} / \mathrm{mg} \mathrm{DW})^{* * *}\end{array}$ \\
\hline $\mathrm{C}_{\mathrm{B}} \mathrm{M} 1$ & $21.20 \pm 0.5^{a}$ & $42.31+0.46^{f}$ & $17.69+0 / 46^{i}$ \\
$\mathrm{C}_{\mathrm{B}} \mathrm{M} 2$ & $45.23 \pm 0.82^{b}$ & $3.75+0.68^{g}$ & $27.01+0.31^{j}$ \\
$\mathrm{C}_{\mathrm{B}} \mathrm{M} 5$ & $30.51+0.47^{c}$ & $67.42+0.51^{h}$ & $53.06+0.61^{k}$ \\
$\mathrm{C}_{\mathrm{B}} \mathrm{M} 6$ & $63.86+0.69^{d}$ & $65.46+0.40^{h}$ & $55.97+0.85^{k}$ \\
$\mathrm{C}_{\mathrm{B}} \mathrm{M} 7$ & $74.17+0.61^{e}$ & 5
\end{tabular}

The extracted contents in extracts are presented as average of three individual experiments. Different alphabets demonstrate significant $(\mathrm{p}<0.05)$ difference in the respective extraction solvents. *Gallic Acid Equivalent, **Quercetin Equivalent, ***Catechin Equivalent, and CBEs $=$ Cleome brachycarpa Extracts

The chemistry involved in TPC assessment is based on phosphomolybdic acid and phosphotungstic acid being the main constituents of Folin-Ciocalteu reagent. In alkaline medium, the phenolics reduce them to bluecolored oxides of molybdenum and tungsten (Yasmeen \& Hassnain 2016). Moreover, in $\mathrm{AlCl}_{3}$ assay for assessment of flavonoids, an alkaline chromogenic system between $\mathrm{NaNO}_{2}, \mathrm{AlCl}_{3}$, and $\mathrm{NaOH}$ builds up which reacts with flavonoids resulting in red chelates and get detected at $510 \mathrm{~nm}$. In case of Vanillin assay for tannins, the unsubstituted resorcinol or phloroglucinol entity of tannins forms colored adducts with vanillin which are delectable at $500 \mathrm{~nm}$ (Saad et al. 2012).

The ascending order of extraction of phenolics from microwave-assisted extracts of Cleome brachycarpa is $\mathrm{C}_{\mathrm{B}} \mathrm{M} 1<\mathrm{C}_{\mathrm{B}} \mathrm{M} 5<\mathrm{C}_{\mathrm{B}} \mathrm{M} 2<\mathrm{C}_{\mathrm{B}} \mathrm{M} 6<\mathrm{C}_{\mathrm{B}} \mathrm{M} 7$. Flavonoids and Tannins' extraction followed the order of $\mathrm{C}_{\mathrm{B}} \mathrm{M} 1<\mathrm{C}_{\mathrm{B}} \mathrm{M} 5$ $<\mathrm{C}_{\mathrm{B}} \mathrm{M} 2<\mathrm{C}_{\mathrm{B}} \mathrm{M} 7 \sim \mathrm{C}_{\mathrm{B}} \mathrm{M} 6$. In both cases, the outcome agreed with the extraction efficiency and phytochemical screening. Similar solvent extraction trend has been supported in a previous study (Medini et al. 2014). It can be anticipated that the chemical nature of phenolics plays a vital role in polyphenols' solubility in different solvents.
The chemical nature may include features such as the extent of polymerization in polyphenols, intermolecular interaction with other polyphenols, complexation and hydrophilicity or hydrophobicity of phenols (Ngo et al. 2017). For example, in some studies acetone was found preferable for extracting polyphenols (Moridi et al. 2017; Shian \& Abdullah 2012).

\section{ANTIOXIDANT POTENTIAL OF GREEN EXTRACTS OF Cleome brachycarpa}

Polyphenols potentially regulate the oxidative stress not only by scavenging the ROs but also by agnostically activating the signal transductions i.e. Polyphenols first scavenge the ROs such as $\mathrm{O}_{2}, \mathrm{OH}, \mathrm{RO}_{2}, \mathrm{HOCl}$, ONOOH and then carry onto interfering the oxidative stress signaling pathway. The mode of the antioxidant activity of phenolics can be based either on single electron transfer by proton transfer or hydrogen atom transfer. In conjugation with assessment of polyphenols, two antioxidant assays were used to determine the antioxidant capacity of Cleome brachycarpa - The DPPH Scavenging Assay and Total Antioxidant Potential Assay.
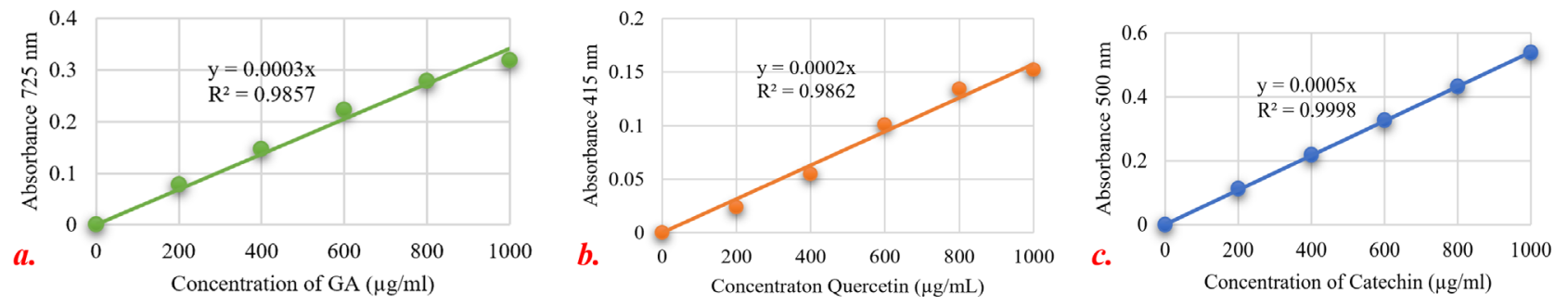

FIGURE 3. Standard curves $(\mu \mathrm{g} / \mathrm{mL})$ for assesment of polyphenolics $a$. Gallic acid for total phelolics content, $b$. quencertin for total flavnoid content, and $c$. catechin for total tannins content 


\section{ROS SCAVENGING ACTIVITY}

Table 3 summaries the DPPH inhibition potential of different concentrations of green extracts of Cleome brachycarpa. DPPH scavenging is a fast and subtle assay to measure their ROs quenching capacity. The chemistry is simple enough; antioxidants are rich in hydroxyl groups which have potential to donate electrons or protons neutralizing the DPPH radical into stable hydrazine which is detected at $517 \mathrm{~nm}$.

TABLE 3. ROs (DPPH) inhibition percentage of green extracts of Cleome brachycarpa

\begin{tabular}{|c|c|c|c|c|c|c|}
\hline \multirow[t]{2}{*}{$\mathrm{C}_{\mathrm{B}} \mathrm{Es}^{*}$} & \multicolumn{5}{|c|}{ Percentage inhibition of various concentrations $(\mu \mathrm{g} / \mathrm{mL})$} & \multirow{2}{*}{$\begin{array}{c}\mathrm{IC}_{50} \\
(\mathrm{mg} / \mathrm{mL})\end{array}$} \\
\hline & 50 & 100 & 200 & 400 & 800 & \\
\hline $\mathrm{C}_{\mathrm{B}} \mathrm{M} 1$ & $6.35 \pm 0.48_{\mathrm{s}}^{\mathrm{e}}$ & $16.18 \pm 0.75_{\mathrm{p}}^{\mathrm{d}}$ & $21.09 \pm 0.25_{\mathrm{n}}^{\mathrm{c}}$ & $29.97 \pm 0.14_{\mathrm{k}, 1}^{\mathrm{b}}$ & $47.09 \pm 0.46_{\mathrm{f}}^{\mathrm{a}}$ & 0.79 \\
\hline $\mathrm{C}_{\mathrm{B}} \mathrm{M} 2$ & $10.81 \pm 0.53_{\mathrm{q}}^{\mathrm{i}}$ & $21.54 \pm 0.09_{\mathrm{n}}^{c}$ & $32.65 \pm 0.32_{j}^{h}$ & $44.22 \pm 0.15_{\mathrm{g}}^{\mathrm{g}}$ & $61.87 \pm 0.51_{c}^{\mathrm{f}}$ & 0.54 \\
\hline $\mathrm{C}_{\mathrm{B}} \mathrm{M} 5$ & $9.67 \pm 0.85_{\mathrm{q}}^{\mathrm{i}}$ & $19.30 \pm 0.44_{\mathrm{o}}^{\mathrm{c}}$ & $29.37 \pm 0.48_{1}^{1}$ & $38.32 \pm 0.42_{\mathrm{i}}^{\mathrm{k}}$ & $56.20 \pm 0.67_{\mathrm{e}}^{\mathrm{j}}$ & 0.62 \\
\hline $\mathrm{C}_{\mathrm{B}} \mathrm{M} 6$ & $18.56 \pm 0.94_{o}^{c}$ & $23.28 \pm 0.53 \stackrel{o}{\mathrm{~m}}$ & $41.23 \pm 0.05_{\mathrm{h}}^{\mathrm{n}}$ & $56.54 \pm 0.46_{\mathrm{e}}^{\mathrm{j}}$ & $77.86 \pm 0.04{ }_{b}^{m}$ & 0.40 \\
\hline $\mathrm{C}_{\mathrm{B}} \mathrm{M} 7$ & $30.73 \pm 0.70_{\mathrm{k}}^{\mathrm{l}}$ & $37.34 \pm 0.51_{\mathrm{i}}^{\mathrm{k}}$ & $48.82 \pm 0.44_{\mathrm{f}}^{\mathrm{a}}$ & $59.98 \pm 0.65 \frac{\mathrm{q}}{\mathrm{d}}$ & $81.37 \pm 0.28_{\mathrm{a}}^{\mathrm{p}}$ & 0.31 \\
\hline Trolox & $34.90 \pm 0.32$ & $37.81 \pm 0.19$ & $43.64 \pm 0.67$ & $55.30 \pm 0.45$ & $78.62 \pm 0.09$ & 0.30 \\
\hline
\end{tabular}

The percentage inhibition of different concentrations of extracts is presented as average of three individual experiments. Different alphabets in superscript demonstrate significant $(\mathrm{p}<0.05)$ difference in various concentrations of same extract whereas different alphabets in subscript exemplifies significant $(\mathrm{p}<0.05)$ difference in combined effect of solvents and concentrations. ${ }^{*} \mathrm{CBEs}=$ Cleome brachycarpa Extracts

Different concentrations $(\mu \mathrm{g} / \mathrm{mL})$ among the extracts showed significant rise $(\mathrm{p}<0.05)$ in the ROs scavenging potential in increasing order. The methanolic green extract of Cleome brachycarpa scavenged the DPPH in range of $30.73 \pm 0.70$ to $81.37 \pm 0.28 \%$ which went slightly higher than the standard 'Trolox' (34.90 \pm 0.32 to 78.62 $\pm 0.09 \%$ ) yet with close $\mathrm{IC}_{50}$ of 0.31 and $0.30 \mathrm{mg} / \mathrm{mL}$ correspondingly. The lower the half-maximal inhibitory concentration $\left(\mathrm{IC}_{50}\right)$, the greater the antioxidant potential is. The least DPPH scavenging was shown by the n-hexanic extract with the $\mathrm{IC}_{50}$ of $0.79 \mathrm{mg} / \mathrm{mL}$. ANOVA and post-hoc tests have shown that percentage inhibition of different concentration is significantly different $(p<0.05)$ within the solvents and among the solvents. The pooled STD is found to be 0.48 whereas the individual confidence level was calculated to be $99.98 \%$ from the Tukey simultaneous tests for Differences of means.

\section{TOTAL ANTIOXIDANT POTENTIAL}

Moderate to high, total antioxidant potential has been demonstrated by the green extracts of Cleome brachycarpa. The results are expressed in equivalency with $\mu \mathrm{g} \mathrm{GA} / \mathrm{mg}$ DW in Figure 4. The effect of concentration and solvent is evident and goes along with the trend of extraction of polyphenols. The total antioxidant potential is commonly assessed with Ferric Reducing Antioxidant Assay. In this assay, the reduction of $\mathrm{Fe}$ in ferricyanide to $\mathrm{Fe}^{+2}$ by polyphenols is measured. The reaction results a Prussian blue colorization, whose intensity indicates the polyphenol's reducing capacity i.e. total antioxidant potential (Yasmeen \& Hassnain 2016). Methanolic green extract of Cleome brachycarpa showed the highest total antioxidant potential. In a similar study done on Euphorbia royleana (Ashraf et al. 2014), the unique trend of solubility of polyphenols in solvents was followed and n-hexanic extract showed the highest total antioxidant potential ( $\mu \mathrm{g}$ GAE/mg DW). 


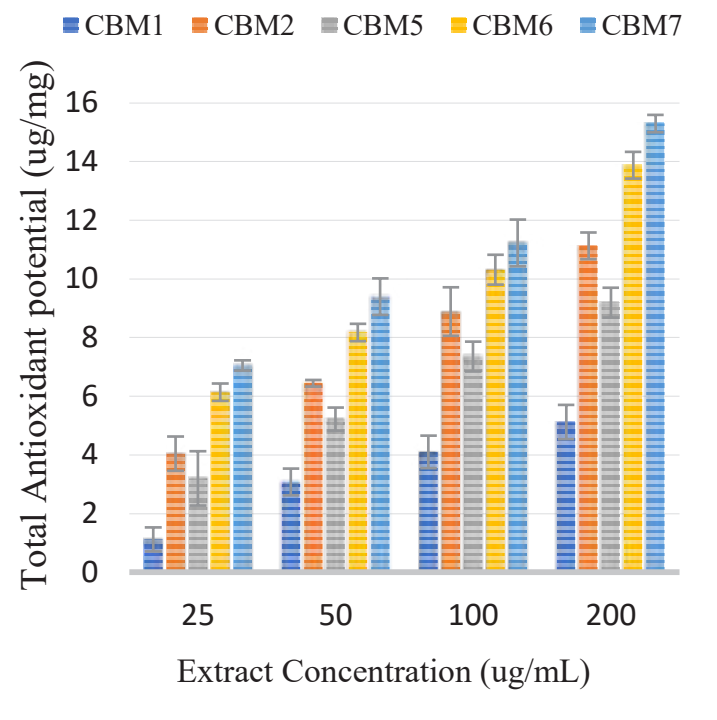

\footnotetext{
FIGURE 4. Total antioxidant potential of various microwaveassisted extracts of Cleome brachycarpa expressed as $\mu \mathrm{g}$ GAE/mg Dry weight. **Values are graphed as mean standard deviation of three replicates
}

Both assays showed that antioxidant capacity agrees with the trend of extraction of polyphenols: $\mathrm{C}_{\mathrm{B}} \mathrm{M} 1<\mathrm{C}_{\mathrm{B}} \mathrm{M} 5<\mathrm{C}_{\mathrm{B}} \mathrm{M} 2<\mathrm{C}_{\mathrm{B}} \mathrm{M} 7 \sim \mathrm{C}_{\mathrm{B}} \mathrm{M} 6$, approving the significant correlation $(\mathrm{p}<0.05)$ of polyphenols with antioxidant capacity of Cleome brachycarpa. Similar trend for antioxidant capacity was observed by previous related studies (Chavan et al. 2013). The findings of present study further support that use of green extraction technology works down right to the efficient extraction of polyphenols, resulting in improved antioxidant capacity when optimized with pertinent solvents.

\section{CONCLUSION}

The present study brought the high antioxidant capacity of Cleome brachycarpa in relation with its polyphenols' estimation. The extraction polyphenols directly regulated the antioxidant capacity of different green extracts. It was found that extraction technology has a great impact in improvising the antioxidant capacity of Cleome brachycarpa. Methanolic-microwave-assisted extracts were most potent in antioxidant capacity - setting a milestone for in-depth study of this extract of Cleome brachycarpa.

\section{ACKNOWLEDGEMENTS}

Authors are grateful to HEC Pakistan for funding this research under the project no. 21-423SRGP/R\&D/ $\mathrm{HEC} / 2014$. Authors declare no conflict of Interest.

\section{REFERENCES}

Abdul Ghani, Zulfaqar Ali \& Saira Perveen. 2012. Folk recipes and ethno botanical survey of medicinal plants Mianwali district (Pakistan). International Journal of Current Pharmaceutical Research 4(2): 61-63.

Aicha, M., Zaghed, N., Halmi, S. \& Belkhiri, A. 2017. Antioxidant activity and phenolic compounds contents of spider flower (Cleome arabica ssp. arabica), a well acclimated species in the Algerian desert areas. European Scientific Journal 13(12): 1857-7881.

Ali, S.I. \& Qaiser, M. 2001. Flora of Pakistan. St. Louis: University of Karachi \& Missouri Botanical Garden.

Ashraf, A., Sarfraz, R.A., Rashid, M.A. \& Shahid, M. 2014. Antioxidant, antimicrobial, antitumor, and cytotoxic activities of an important medicinal plant (Euphorbia royleana) from Pakistan. Journal of Food and Drug Analysis 23(1): 109-115.

Azmir, J., Zaidul, I.S.M., Rahman, M.M., Sharif, K.M., Mohamed, A., Sahena, F., Jahurul, M.H.A., Ghafoor, K., Norulaini, N.A.N. \& Omar, A.K.M. 2013. Techniques for extraction of bioactive compounds from plant materials: A review. Journal of Food Engineering 117(4): 426-436.

Bainiwal, L.K., Vijayvergia, P. \& Vijayvergia, R. 2013. Determination of preliminary phytoconstituents, total phenolic and flavonoids contents in the roots, leaves and stems of Cleome viscosa Linn. International Journal of Biological And Pharmaceutical Research 4(12): 891-895.

Bhattacharyya, A., Chattopadhyay, R., Mitra, S. \& Crowe, S.E. 2014. Oxidative stress: An essential factor in the pathogenesis of gastrointestinal mucosal diseases. Physiological Reviews 94(2): 329-354. 
Chavan, J.J., Jagtap, U.B., Gaikwad, N.B., Dixit, G.B. \& Bapat, V.A. 2013. Total phenolics, flavonoids and antioxidant activity of Saptarangi (Salacia chinensis L.) fruit pulp. Journal of Plant Biochemistry and Biotechnology 22(4): 409-413.

Cvjetko Bubalo, M., Vidović, S., Radojčić Redovniković, I. \& Jokić, S. 2015. Green solvents for green technologies. Journal of Chemical Technology and Biotechnology 90(9): 1631-1639.

Do, Q.D., Angkawijaya, A.E., Tran-Nguyen, P.L., Huynh, L.H., Soetaredjo, F.E., Ismadji, S. \& Ju, Y.H. 2014. Effect of extraction solvent on total phenol content, total flavonoid content, and antioxidant activity of Limnophila aromatica. Journal of Food and Drug Analysis 22(3): 296-302.

Ekor, M. 2013. The growing use of herbal medicines: Issues relating to adverse reactions and challenges in monitoring safety. Frontiers in Pharmacology 47: 777-780.

Farnsworth, N.R. 1966. Biological and phytochemical screening of plants. Journal of Pharmaceutical Sciences 55(3): 225276.

Flores-Cordova, M., Muñoz-Márquez, E., Muñoz-Márquez, E., Ojeda-Barrios, D.L., Soto-Parra, J.M. \& Preciado-Rangel, P. 2017. Phytochemical composition and antioxidant capacity in Mexican pecan nut. Emirates Journal of Food and Agriculture 29(5): 346-350.

Gupta, N.K. \& Vinod K.D. 2009. Hepatoprotective activity of Cleome viscosa Linn. extract against thioacetamide-induced hepatotoxicity in rats. Natural Product Research 23(14): 1289-1297.

Hameed, M., Ashraf, M., Al-Quriany, F., Nawaz, T., Ahmad, M.S.A., Younis, A. \& Naz, N. 2011. Medicinal flora of the Cholistan Desert: A review. Pakistan Journal of Botany 43: 39-50.

Lopresto, C.G., Petrillo, F., Casazza, A.A., Aliakbarian, B., Perego, P. \& Calabrò, V. 2014. A non-conventional method to extract D-limonene from waste lemon peels and comparison with traditional Soxhlet extraction. Separation and Purification Technology 137: 13-20.

Medini, F., Fellah, H., Ksouri, R. \& Abdelly, C. 2014. Total phenolic, flavonoid and tannin contents and antioxidant and antimicrobial activities of organic extracts of shoots of the plant Limonium delicatulum. Journal of Taibah University for Science 8(3): 216-224.

Moridi Farimani, M., Nazarianpoor, E., Rustaie, A. \& Akhbari, M. 2017. Phytochemical constituents and biological activities of Cleome iberica DC. Natural Product Research 31(11): 1329-1332.

Mothana, R.A.A. \& Ulrike, L. 2005. Antimicrobial activity of some medicinal plants of the Island Soqotra. Journal of Ethnopharmacology 96(1): 177-181.

Mussarat, S., AbdEl-Salam, N.M., Tariq, A., Wazir, S.M., Ullah, R. \& Adnan, M. 2014. Use of ethnomedicinal plants by the people living around Indus River. Evidence-Based Complementary and Alternative Medicine 2014: Article ID. 212634.

Mustapa, A.N., Martin, A., Gallego, J.R., Mato, R.B. \& Cocero, M.J. 2015. Microwave-assisted extraction of polyphenols from Clinacanthus nutans Lindau medicinal plant: Energy perspective and kinetics modeling. Chemical Engineering and Processing: Process Intensification 97: 66-74.
Ngo, T.V., Scarlett, C.J., Bowyer, M.C., Ngo, P.D. \& Vuong, Q.V. 2017. Impact of different extraction solvents on bioactive compounds and antioxidant capacity from the root of Salacia chinensis L. Journal of Food Quality 2017(1): 1-8.

Saad, H., Charrier-El Bouhtoury, F., Pizzi, A., Rode, K., Charrier, B. \& Ayed, N. 2012. Characterization of pomegranate peels tannin extractives. Industrial Crops and Products 40: 239246.

Saad, H., Charrier-El Bouhtoury, F., Pizzi, A., Rode, K., Charrier, B. \& Ayed, N. 2011. Extraction, isolation and characterization of bioactive compounds from plants' extracts. African Journal of Traditional, Complementary and Alternative Medicines 8(1): 1-10.

Shian, T.E. \& Abdullah, A. 2012. Antioxidant properties of three banana cultivars (Musa acuminata 'Berangan', 'Mas' and 'Raja') extracts. Sains Malaysiana 41(3): 319-324.

Smith, R.M. 2003. Before the injection - Modern methods of sample preparation for separation techniques. Journal of chromatography A 1000(1): 3-27.

Tsao, R. 2010. Chemistry and biochemistry of dietary polyphenols. Nutrients 2(12): 1231-1246.

Vinatoru, M., Mason, T.J. \& Calinescu, I. 2017. Ultrasonically assisted extraction (UAE) and microwave assisted extraction (MAE) of functional compounds from plant materials. Trends in Analytical Chemistry 97: 159-178.

Yasmeen, H. \& Hassnain, S. 2016. Comparative analysis of different bioactivities of Curcuma longa, Nigella sativa seeds, and Camellia sinensis extracted by four different methods: A green way to reduce oxidative stress. Food Science and Biotechnology 25(3): 811-819.

Zapata Londoño, M.B., Chaparro Rojas, D.C., Rojano, B.A., Alzate Arbeláez, A.F., Restrepo Betancur, L.F. \& Maldonado Celis, M.E. 2017. Effect of storage time on physicochemical, sensorial, and antioxidant characteristics, and composition of mango (cv. Azúcar) juice. Emirates Journal of Food and Agriculture 29(5): 367-377.

Zarza-García, A.L., Sauri-Duch, E., Raddatz-Mota, D., CuevasGlory, L.F., Pinzón-López, L.L., Rivera-Cabrera, F. \& Mendoza-Espinoza, J. 2017. Pharmacological, phytochemical and morphological study of three Mayan accessions of Bixa orellana L. leaves. Emirates Journal of Food and Agriculture 29(3): 163-169.

Tahira Saleem, Ayesha Sumra, Samra Khan*, Warda Hassan, Sehrish Mehdi, Noor-ul-Ain Wahid \& Samrah Kanwal \& Tehseen Gull

Department of Chemistry

The Women University Multan

Multan, 60000

Pakistan

Maryam Zain

Department of Chemistry, Institute of Chemical Sciences

Bahauddin Zakariya University

Multan, 60800

Pakistan

Ayesha Sumra \& Maryam Zain

Department of Biochemistry and Biotechnology

The Women University Multan

Multan, 60000

Pakistan 
Tehseen Gull

Department of Chemistry

University of Agriculture Faisalabad

Faisalabad, 38000

Pakistan
*Corresponding author; email: samra_zahid@live.com

Received: 2 April 2019

Accepted: 10 April 2020 